\title{
Nosema ceranae disease of the honey bee (Apis mellifera)
}

\author{
Mike GoBLIRSCH \\ Department of Entomology, University of Minnesota, 219 Hodson Hall, 1980 Folwell Ave, St. Paul, MN 55108, USA
}

Received 26 October 2016 - Revised 13 March 2017 - Accepted 26 July 2017

\begin{abstract}
The presence of honey bees in our landscapes has long invoked images of vitality, diligence, and cooperation. Unfortunately, the current state of bee health paints a rather different picture. The survival of honey bees, as well as the livelihoods of those who benefit from their labor, is under threat from several detractors to bee health. Exposure to pesticides, poor forage, mite parasites, and pathogens has resulted in high annual death of colonies in the USA, Europe, and other parts of the world. Among the suspects thought to contribute to bee decline, the fungal pathogen, Nosema ceranae, is found at high prevalence in both healthy and declining colonies. Since $N$. ceranae is thought to be a recent parasite of Apis mellifera, much remains unknown about its pathology at the individual and colony levels, as well as how infection may interact and synergize with other stressors. A review of research conducted on N. ceranae infection is provided. Attention is given to observations on detection of infection, cytopathology, viability and infectivity of spores, and caste-specific effects to survival, development, physiology, and behavior. Research findings showing effects from interactions with pesticides and viruses are also provided. Comparisons are drawn between $N$. ceranae and what is known about a similar, long-recognized pathogen of A. mellifera, Nosema apis. When possible, suggestions for future research that could broaden understanding of $N$. ceranae and ultimately improve honey bee health are offered to link observations on individual bee pathology with pathology observed at the colony level.
\end{abstract}

\section{fungal pathogen / Microsporidia / nosemosis / social behavior}

\section{A NEW NOSEMA}

In the aftermath of colony collapse disorder, surveillance efforts have recorded the presence of a "new Nosema" traditionally associated with the Asian honey bee, Apis cerana, in colonies of the European honey bee, Apis mellifera. The detection of this new Nosema sp., Nosema ceranae, as a natural infection of A. mellifera was first reported in Europe in 2006 (Higes et al. 2006). Since then, there have been regular reports on the incidence of $N$. ceranae in A. mellifera and other host species from many parts of the world, supporting a widespread distribution of this parasite (Klee et al. 2007; Chen et al. 2008). The widespread distribution of

Corresponding author: M. Goblirsch, goblirmj@umn.edu

Manuscript editor: Yves Le Conte
$N$. ceranae has caused reason for concern for managed populations of $A$. mellifera and potentially other novel bee hosts. Because A. mellifera is considered to be a recent host, it raises questions as to the effects this pathogen has on host physiology, behavior, and longevity at the individual, as well as colony, level. The goal of this review is to highlight research findings that have contributed to our understanding of disease caused by N. ceranae. Additionally, this review is meant to further the discussion concerning the impact $N$. ceranae has mainly on A. mellifera and how it compares to nosemosis, the disease traditionally associated with Nosema apis, a similar pathogen long recognized to cause infection in A. mellifera (Zander 1909; for an excellent review of nosemosis and $N$. apis, the reader is referred to Fries 1993).

$N$. ceranae likely originated with Apis cerana as its primary host (Fries et al. 1996; Botías et al. 2012). However, archived samples suggest that $N$. ceranae had an expanded geographic and host 
range decades before first detection as natural infections of A. mellifera in Spain (Higes et al. 2006) and the USA (Cox-Foster et al. 2007; Huang et al. 2007). Two studies examining preserved specimens of honey bees by polymerase chain reaction (PCR) analysis place $N$. ceranae in the USA as early as 1975 (Traver and Fell 2015). Samples collected in Finland between 1986 and 2006 showed that samples from as early as 1998 were positive for N. ceranae (Paxton et al. 2007). Likewise, archived material revealed that samples from as early as 1993 from Italy (Ferroglio et al. 2013), 1994 from Canada (Currie et al. 2010), and 1995 from Mexico (Guerrero-Molina et al. 2016) were positive for $N$. ceranae. Moreover, one sample of A. mellifera from Uruguay collected prior to 1990 was positive for $N$. ceranae by PCR (Invernizzi et al. 2009). In addition, Africanized drones collected in Brazil in 1979 had presence of spores by microscopy and were positive for N. ceranae by PCR (Teixeira et al. 2013). Clark (1980) described a second microsporidian in bees from southeastern USA; however, it is unlikely to have been $N$. ceranae due to the presence of a single nucleus instead of the diplonucleus characteristic of spores in this species.

Although the timing of $N$. ceranae's introduction as a pathogen of $A$. mellifera is uncertain, it may have coincided with the spread of the mite parasite, Varroa destructor. As the movement of A. mellifera colonies into and out of regions where A. cerana is endemic lead to the introduction of the $V$. destructor as a parasite of A. mellifera, the interactions of these bee species may also have permitted the simultaneous acquisition and spread of $N$. ceranae. One question that remains unanswered: if $N$. ceranae has been present in colonies of $A$. mellifera for several decades, why has it only recently been considered as a factor in the decline of $A$. mellifera and only in some regions?

\section{DETECTION AND DIAGNOSIS}

The first step in understanding the effects of $N$. ceranae is the ability to detect and diagnose this pathogen. Diagnosis of Nosema spp. infection can be determined by viewing and counting spores with a hemocytometer under magnification
(Cantwell 1970). Nosema spp. spores have a distinct size and ovoid morphology that sets them apart from other microbes in tissue homogenates prepared from honey bees. Coupled with sampling of specific cohorts, the method developed by Cantwell (1970) can provide information on the proportion infected against a specific parameter (e.g., proportion of infected foragers). Although visualizing Nosema spp. spores under a microscope is relatively straightforward, and some skilled technicians may be able to discern between spores of $N$. apis and $N$. ceranae by eye, positive identification to species is complicated by the fact that both species cause single or mixed infections in A. cerana and A. mellifera (Chen et al. 2009; Forsgren and Fries 2010; Milbrath et al. 2015). Evidence suggests that infections with $N$. ceranae are now more prevalent in some regions where $N$. apis had historically been the only species present (Klee et al. 2007; Martín-Hernández et al. 2012; Emsen et al. 2016); therefore, failure to diagnose a mixed infection is likely if the infection is skewed heavily toward one species. Mixed infections that are skewed in favor of a single species point to the need for a reliable detection method specific to the level of species. Progress has been made using fluorescent dyes incorporated with microscopic techniques. For example, the fluorescent brightener, calcofluor white, has been shown to bind to chitin in the cell wall of mature $N$. ceranae spores (Snow 2016). Since immature spores lack chitin, this method is useful for localization studies of mature spores within cells, but it cannot differentiate between species (Snow 2016). Other detection markers, such as labeled antibodies (Aronstein et al. 2013), are needed to discern species and life stages. Species-specific antibodies could be applied toward the development of field assays permitting rapid diagnosis.

Alternatively, PCR amplification of genes encoding ribosomal RNA (rRNA) that are highly conserved within a species but variable between species has the potential to increase specificity and sensitivity of detection and quantification (Chen et al. 2009; Carletto et al. 2013; but see Ptaszyńska et al. 2014 on loop-mediated isothermal amplification). One study compared the specificity and sensitivity of microscopy to real-time 
PCR and showed that the former failed to identify $N$. ceranae spores in $50 \%$ of samples that tested positive by PCR (Traver and Fell 2011a). This finding may demonstrate a disparity between species in the production of spores, where $N$. ceranae may not be as prolific as $N$. apis (MartínHernández et al. 2009; Mulholland et al. 2012). It could also point to the considerable variability observed in sequences of rRNA genes from isolates of N . ceranae (Sagastume et al. 2011). Heterogeneity among $N$. ceranae isolates could result in the failure of probes to amplify a specific target. Higes et al. (2013a) speculate as to the origin of the uncharacteristic heterogeneity observed for $N$. ceranae rRNA genes and suggest the need for alternative markers for taxonomic characterization. The availability of fully sequenced genomes for $N$. apis (Chen et al. 2013) and $N$. ceranae (Cornman et al. 2009) coupled with the sequencing of PCR products could help resolve issues in properly discerning species, as well as haplotypes within species (e.g., $N$. ceranae).

\section{ACQUISITION OF SPORES AND TISSUE TROPISM}

Vegetative forms and immature spores of $N$. apis and $N$. ceranae have only been observed in midgut epithelial cells (Higes et al. 2007; García-Palencia et al. 2010). However, N. apis and $N$. ceranae have been detected by PCR in hypopharyngeal glands, salivary glands, fat body, and Malpighian tubules, but not brain or muscle (Chen et al. 2009; Gisder et al. 2010; Copley and Jabaji 2012; Huang and Solter 2013). Outside the gut, environmental spores of $N$. apis and $N$. ceranae have been observed on the mouthparts of workers and in semen from drones, pointing to possible mechanisms of horizontal transmission via trophallaxis (Smith 2012; Huang and Solter 2013) and vertical transmission via sexual contact (Peng et al. 2015; Roberts et al. 2015), respectively. Although late larval and pupal mortality caused by $N$. apis was observed in the Cape honey bee (Buys 1972), additional evidence is lacking as to whether the egg, larva, or pupa are susceptible to infection under natural conditions. In contrast to some species of Nosema (Raina et al. 1995; Terry et al. 1997), there is no evidence of transovarial transmission from an infected queen to her eggs (Roberts et al. 2015). The lack of vertical transmission may result from tissue tropism restricting the pathogen to infection within midgut epithelial cells or from immune defenses in semen (Peng et al. 2016, see below).

$N$. apis spores have been observed in the hemolymph of larvae (Gilliam and Shimanuki 1967), and drone pupae have tested positive by PCR for N. ceranae (Traver and Fell 2011b). $N$. ceranae has also been detected by PCR in royal jelly (Cox-Foster et al. 2007). Positive detection of spores or DNA in royal jelly supports the likelihood that immatures are exposed through brood food. Although one study was unsuccessful at infecting larvae with N. apis (Hassanein 1953), a more recent study showed the presence of developing spores within the midgut of prepupae provisioned with $N$. ceranae spores as 3-day-old larvae (Eiri et al. 2015). Moreover, Eiri et al. (2015) showed that infection as a larva can have a negative effect on adult longevity. Surveillance for infection in immatures is not typically performed; however, studies conducted in the field where larvae are inspected could provide information on infection frequency and intensity.

\section{PATHOGEN DEVELOPMENT AND CYTOPATHOLOGY}

The interaction of an obligate intracellular pathogen and the host cell is an exchange where the pathogen exploits host cell machinery to obtain resources and the host deploys defense mechanisms (e.g., apoptosis) to limit infection and replication. This interaction can be observed through histological and molecular approaches. Although there may be differences in the timing of specific infection events, the fine morphology and trajectory of development has been described in detail and is similar between $N$. apis and $N$. ceranae (Gray et al. 1969; Youssef and Hammond 1971; Liu 1984, 1989; Fries 1988, 1989a, b; de Graaf et al. 1994; Fries et al. 1996; Higes et al. 2007; Chen et al. 2009). True to their genus, N. apis and $N$. ceranae are diplokaryotic throughout their life cycle. Spores gain access to the host cell and initiate proliferation by rapidly extruding a long 
tube that is attached anteriorly to the spore by an anchoring disc (Xu and Weiss 2005). The extruded polar filament of a germinated spore penetrates a host cell, providing a conduit for the transfer of the binucleate sporoplasm (Figure 1). Presporal development, or merogony, begins within hours after inoculation with the sporoplasm. Merogony proceeds through a variable number of nuclear and/or cytoplasmic divisions. Binary fission leads to the production of clusters or chains of meronts, which are often quadrinucleate (Gray et al. 1969; Fries et al. 1996; Higes et al. 2007). Meronts of $N$. apis and $N$. ceranae have a single thin plasma membrane that remains in direct contact with the host cytoplasm and is similar to the early developmental stages of a related genus, Vairimorpha (Cali et al. 2011). There is no evidence for formation of a parasitophorous vacuole as displayed by members of the genus Encephalitozoon (Youssef and Hammond 1971; Scanlon et al. 2004). Not all Microsporidia utilize a parasitophorous vacuole as part of their development. The function of this organelle is purported to be an exploitation strategy of the pathogen in that the meront repositions host mitochondria along the interface of the vacuole to increase the surface area for the import of host ATP (Hacker et al. 2014). The absence of the parasitophorous vacuole in Nosema spp. leads to the possibility that this genus uses other means of obtaining a continuous supply of ATP from the host, such as nucleotide transporters embedded in the plasma membrane of the parasite (Tsaousis et al. 2008). Numerous mitochondria and free ribosomes have been observed surrounding the plasmalemma of meronts of $N$. ceranae (Higes et al. 2007).

Meronts of $N$. apis and $N$. ceranae transform into either the primary spore or mature, environmental spore between 48 and $96 \mathrm{~h}$ after infection (Fries 1988; de Graaf et al. 1994; Higes et al. 2007). The primary spore is produced through binary fission of the sporont to form two sporoblasts, each having a thin spore wall and short polar filament. The primary spore is capable of transmitting infection to adjacent cells through autoinfection (i.e., spontaneous germination) (Becnel and Andreadis 1999). The major differences in development and morphology between the primary spore and the mature spore are the thick spore wall and longer polar filament of the later. Ultimately, an infected cell becomes tightly packed with parasites, leading to the rupture and release of spores into the gut lumen. Mature spores can pass through the rectum in the feces, serving as an inoculum for other bees, or they can remain in the midgut to infect other cells.

Cells infected with Nosema spp. show extensive lysis or degeneration (Liu 1984; Higes et al.

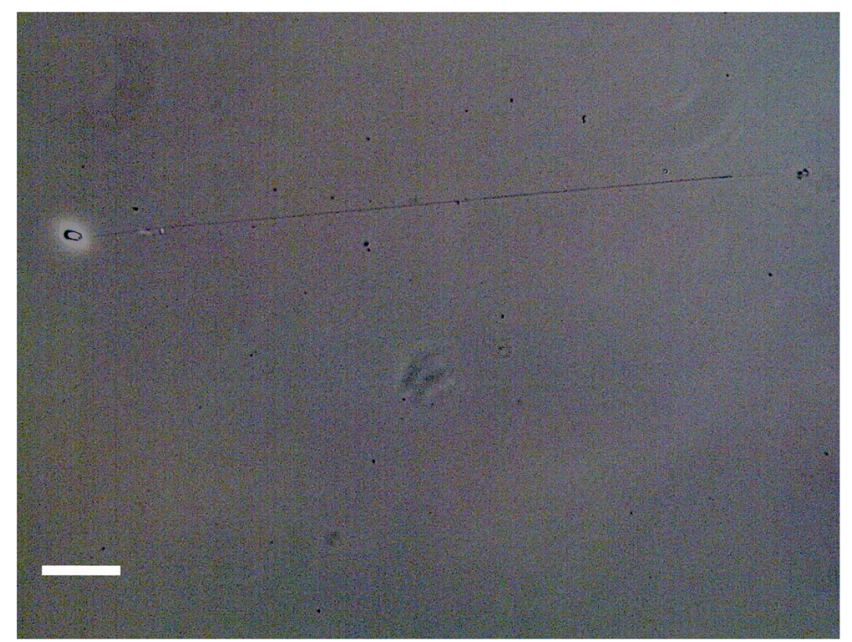

Figure 1. Germinated spore with extruded polar filament and sporoplasm. Purified spores were air-dried on glass slides followed by activation of germination by incubation with $0.5 \mathrm{M} \mathrm{NaCl} / 0.5 \mathrm{M} \mathrm{NaHCO}_{3}$ solution for 30 min at $37^{\circ} \mathrm{C}$. Scale bar $=20 \mu \mathrm{m}$. 
2007; Dussaubat et al. 2012). Other indicators of cell injury include a loss of glycogen particles and detachment of ribosomes from the rough endoplasmic reticulum (RER) (Liu 1984). Loss of glycogen and loose aggregation of ribosomes may be a consequence of damage to mitochondria (Kumar et al. 2012). Utilization of glycogen reserves indicates that an infected cell has switched from a more efficient means of energy production (i.e., oxidative phosphorylation) to less efficient anaerobic glycolysis, possibly to compensate for competition/depletion of ATP by the amitochondriate Nosema spp. As ATP is depleted, it is unavailable to drive the flow of ions across membranes. Pump failure retains sodium within the cell and causes swelling of the RER and detachment of ribosomes, resulting in necrosis (Kumar et al. 2012). Host cells likewise can proceed through programmed death, or apoptosis.

Measuring the activity of specific enzymes or levels of substrates involved with cascades of cell death has been used to explore whether infected cells proceed through apoptosis or necrosis. TUNEL assay and immunohistochemistry for caspase-3 have been used to examine apoptosis in midgut cells infected with $N$. ceranae. In a healthy cell, caspase- 3 is inactive; however, early in the process of apoptosis, the proenzyme is cleaved, and the residues dimerize to the active form. Fragmented or damaged DNA late in apoptosis provides the substrate for terminal deoxynucleotidyl transferase to catalyze the addition of dUTP. Higes et al. (2013b) concluded that $N$. ceranae inhibits apoptosis as caspase- 3 and dUTP-labeled molecules were widely distributed in uninfected tissues, but had negligible presence in infected tissues. A subsequent study confirmed that $N$. ceranae inhibits apoptosis at specific stages during parasite development and may be dependent on the host species (Gregorc et al. 2016). These findings reinforce what may be the norm for Microsporidia (Scanlon et al. 1999), and alludes to a conserved strategy utilized by intracellular microorganisms (Nash et al. 1998). For $N$. ceranae, this strategy may involve virulence factors expressed early during infection that bind and limit the activity of proapoptotic proteins responsible for releasing toxic molecules from host mitochondria (Huang et al. 2016). Interestingly, bees tolerant to $N$. ceranae may be less sensitive to apoptosis induced by parasite manipulation (Kurze et al. 2016a). The ultimate outcome for an infected cell is likely death, but understanding the mechanism is important for determining the degree by which it is mediated by the host to limit the spread of infection or whether the pathogen has some control over host metabolic processes.

\section{VIABILITY AND INFECTIVITY}

Bees become infected with Nosema spp. by ingesting spores. Sources of spores in the environment include comb and water that has been contaminated with feces. Spores of N. ceranae have been found in the corbicular pollen of foragers, and these spores can cause infection (Higes et al. 2008). This finding suggests that floral resources can become contaminated with feces from an infected bee or transferred from the body of a foraging worker. The presence of spores on flowers points to these shared resources as a significant source of pathogen dispersal. Graystock et al. (2015) demonstrate this by showing that uninfected host and nonhost bees can vector pathogens (e.g., N. apis and N. ceranae) from contaminated flowers to flowers not previously visited. Spores acquired from flowers during foraging may become mixed with pollen during grooming and are likely deposited in comb cells upon returning to the hive. Workers performing comb cleaning are more likely to become infected than queens and drones that do not perform these behaviors (Fries 1993). As bees emerge from pupation, they may also become infected as they chew through contaminated wax (Malone and Gatehouse 1998). The potential for exposure to spores in the hive increases when inclement weather prevents cleansing flights by infected bees (Moeller 1972; Retschnig et al. 2017).

Factors that affect viability can be determined by exposing spores to different storage conditions such as temperature, time, and reagents. The number of viable spores needed to cause infection in 50 and $100 \%$ of workers has been found to be comparable for both $N$. apis and $N$. ceranae and are in the range of $10^{2}$ and $10^{4}$ spores, respectively (Forsgren and Fries 2010). The viability of $N$. ceranae spores treated with brief exposure (1, 
2,4 , or $6 \mathrm{~h}$ ) to temperatures of 35 or $60^{\circ} \mathrm{C}$ were assessed using SYTOX Green (Fenoy et al. 2009). Spores inspected immediately or 1 month after treatment showed comparable levels of staining to control spores held at $4{ }^{\circ} \mathrm{C}$ for 1 month in $1 \times$ PBS $(\geq 92.0 \%)$. However, maintaining $N$. ceranae and $N$. apis spores at $4{ }^{\circ} \mathrm{C}$ in PBS for an extended period was not sufficient to sustain viability as levels declined by one third and three quarters after 6 and 12 months, respectively (Fenoy et al. 2009). More recently, the effect of cryopreservation $\left(-70{ }^{\circ} \mathrm{C}\right)$ on viability was assessed for N. ceranae (McGowan et al. 2016). Spores stored in water or $10 \%$ glycerol were comparable to freshly isolated spores; however, there was a significant reduction in infectivity for spores stored at $-70{ }^{\circ} \mathrm{C}$ (McGowan et al. 2016).

Although used less frequently, flow cytometry can provide an efficient and reproducible method for assessing viability (Peng et al. 2014). Spores that were freshly isolated, stored for 20 days at room temperature, or autoclaved were then segregated by light scattering filters to determine size and complexity. From these populations, the intensity of propidium iodide (PI) fluorescence was measured to differentiate viable spores from PIpositive (i.e., dead) spores (Sánchez Collado et al. 2014). Using this method, the percentage of dead spores was found to be $<15 \%$ for both $N$. apis and $N$. ceranae after 10 months at $4{ }^{\circ} \mathrm{C}$ or room temperature. Storage for 10 months at $33{ }^{\circ} \mathrm{C}$ for both species and $-20{ }^{\circ} \mathrm{C}$ for $N$. ceranae decreased viability by $\geq 50 \%$ in all cases. Reduction in viability was also correlated to decreased infectivity when treated spores were fed to uninfected bees (Sánchez Collado et al. 2014).

Spores may appear viable, but they may not be infectious. In other words, spores may not be competent to respond to stimuli in the gut and complete germination. Determining whether spores exposed to different conditions are infectious can be achieved by administering them to bees and measuring outcomes such as proportion infected and/or spore production. Malone et al. (2001) dried spores of $N$. apis on glass slides held at $33,40,45$, and $49^{\circ} \mathrm{C}$ for 3 or 5 days. Spores were then suspended in sucrose solution and fed to bees. Approximately half as many bees became infected from spores stored at
40,45 , and $49^{\circ} \mathrm{C}$ compared to spores stored at $33{ }^{\circ} \mathrm{C}$ or spores stored at room temperature for $24 \mathrm{~h}$, suggesting that temperature is one factor that influences germination (Malone et al. 2001).

Activation and completion of germination remains a poorly understood process. The large diversity of hosts and external environments where Microsporidia exist indicates that this process is host specific. Differences in germination have been demonstrated between N. apis and $N$. ceranae spores stored at low temperatures $\left(4{ }^{\circ} \mathrm{C}\right)$. Freshly isolated spores dried on glass slides kept at $4{ }^{\circ} \mathrm{C}$ for 4 days showed that $80 \%$ of N. apis, compared to $10 \%$ of N. ceranae spores, germinated in the presence of $0.1 \mathrm{M}$ sucrose in PBS (Gisder et al. 2010). Gisder et al. (2010) also noted that the extruded filament of many $N$. ceranae spores was relatively short, suggesting that the spores observed may have been the primary life stage and not the environmental form. It is likely that the primary spore requires different conditions to activate and complete germination compared to the environmental spore.

\section{COMPARATIVE VIRULENCE}

Evidence points to $N$. ceranae as being more prevalent and producing higher spore loads than N. apis (Paxton et al. 2007; Emsen et al. 2016); however, current trends in Europe suggest that infection with Nosema spp., in general, has become less prevalent in recent years (Laurent et al. 2016). Caged bees infected with $N$. apis, $N$. ceranae, or both species can be used to provide insight into differences in growth rate, infectivity, and transmission, as well as for comparing consequences to host physiology, such as immune response or survivorship. For example, infection of bees with $10^{5} \mathrm{~N}$. ceranae spores has been shown to produce $100 \%$ mortality 8 days after infection (Higes et al. 2007). Williams et al. (2014) compared spore loads and mortality between $N$. apis, $N$. ceranae, or mixed species and found that bees infected with $N$. ceranae had significantly increased mortality, but only increased spore load compared to bees infected with both species. Forsgren and Fries (2010) infected newly emerged bees with $10,10^{2}, 10^{3}$, and $10^{4}$ spores of 
$N$. apis or $N$. ceranae, doses $\leq 10$-fold lower than Higes et al. (2007), and noticed a slower rate of increase in $N$. ceranae spore number compared to $N$. apis. This difference was temporary, as spore load and proportion infected were equivalent between species 14 days after infection (Forsgren and Fries 2010). In addition, Forsgren and Fries (2010) examined within host competition from mixed infections using inocula of 1:9, 9:1, or equal ratios of species. The species with the lower inoculum produced a greater number of spores 14 days after infection, and it is hypothesized that this effect may have been due to negative frequency-dependent selection (Forsgren and Fries 2010). Negative frequency-dependent selection is a mechanism explaining how asexually reproducing organisms maintain genetic diversity within an essentially clonal population, ultimately leading to the development of unique haplotypes (Weeks and Hoffmann 2008). Multiple haplotypes have been detected in isolates of $N$. ceranae from individual bees and different geographic regions (Williams et al. 2008; Gómez-Moracho et al. 2014). Intraspecies variation within $N$. ceranae may explain why isolates from Spain are more virulent than isolates from other regions (Paxton et al. 2007); however, Dussaubat et al. (2013) found no genetic differences in isolates from Spain that demonstrate high virulence versus isolates from France that have low virulence. An alternative explanation for why $N$. ceranae does not have as pronounced of an effect on bees outside of Spain may pertain to host tolerance, as bees in Denmark, for example, have been under artificial selection against Nosema spp. for decades (Huang et al. 2012, 2014).

Attributing the severity of disease based on spore load can be misleading (Zheng et al. 2014). Bees that are infected but are otherwise asymptomatic can have either high or low spore loads (Meana et al. 2010). For example, a recent study suggests that challenge alone with $N$. ceranae can have negative effects on host fitness, such as learning rate in bumblebees, despite a lack of spore production (Piiroinen and Goulson 2016). If exposure to N. ceranae without subsequent infection is sufficient to induce a negative effect, then the impact to overall colony health may extend beyond infected individuals.

\section{E F F E C T S O N C O L O N Y DEMOGRAPHY}

\subsection{Effects on queen health}

$N$. ceranae can be transmitted horizontally from infected workers to the queen (Higes et al. 2009). It has been shown previously that queens infected with $N$. apis are more likely to be replaced through supersedure (Farrar 1947; Furgala 1962; Jay 1967). Alaux et al. (2011) looked at the profile of queen mandibular pheromone (QMP) as a proximate mechanism to explain above normal frequencies of supersedure due to infection. Findings showed that levels of the QMP compounds, 9-oxodec-2-enoic acid (9-ODA) and 9-hydroxy2-enoic acid (9-HDA), were significantly greater, while methyl $p$-hydroxybenzoate (HOB), an antifungal, was significantly lower, in the heads of queens infected with $N$. ceranae (Alaux et al. 2011). Declining HOB may be one signal that prompts initiation of queen rearing. Further research is needed to determine whether concentrations of HOB produced from queens infected with $N$. ceranae under laboratory conditions are capable of altering worker behavior when administered in the hive. Interestingly, HOB is an antifungal commonly added to artificial diets used to rear insects (Cohen 2003). Although speculative, suppression of HOB production may facilitate Nosema spp. growth and transmission.

Infection can induce changes to other factors linked to queen reproductive health. Terminal oocytes of queens infected with $N$. apis show evidence of autolysis, and mitochondria, endoplasmic reticulum, ribosomes, and yolk granules appear unevenly dispersed or in a state of deterioration (Liu 1992). While yolk material undergoes degeneration in the ovaries, levels of the yolk precursor protein, vitellogenin $(\mathrm{Vg})$, increase in the hemolymph of infected queens. Eight days after inoculation, queens infected with $N$. ceranae were found to have nearly twice the amount of Vg as controls (Alaux et al. 2011). The reason $\mathrm{Vg}$ is elevated in the hemolymph is unclear. Vitellogenin is continuously synthesized in the fat body and secreted in the hemolymph of mature queens (Fluri et al. 1981), where it is routed to the ovaries for egg maturation 
(Hagedorn and Kunkel 1979). Elevated Vg levels in the hemolymph of infected queens may be a temporary condition due to deterioration of specific receptors on ovaries that facilitate uptake.

\subsection{Effects on drone health}

The contribution of drones in shaping colony health may be overlooked when identifying the impact of infectious diseases. However, the degree of genetic variation due to different patrilines allows variability in responses for a colony confronted with stressors such as pathogens. Drone pupae and adults are susceptible to natural infection with $N$. ceranae (Traver and Fell 2011b). While spore loads may not reach levels as seen in workers, evidence suggests that infection with $N$. ceranae has a greater negative effect on drone body mass and survival (Retschnig et al. 2014a). A decrease in survival has also been observed in drones experimentally infected with $N$. apis (Peng et al. 2015). These findings raise important questions about drone health. Do infected drones weigh less because workers recognize that they are infected and stop feeding them to reduce transmission? Is there an effect to the quality or quantity of sperm in infected drones? Although $N$. ceranae is restricted to tissues outside the genital tract, infection may contribute to changes in somatic processes that ultimately reduce fertilization and reproductive success.

Male social insects are thought to maintain high reproductive potential by investing in the production of abundant, high-quality sperm (den Boer et al. 2010). However, with this investment comes a trade-off: a reduction in the allocation of resources for nonreproductive processes such as the immune system (Baer et al. 2006). The susceptibility of honey bees to diseases and parasites puts the reproductive potential of drones, and the colony, at risk. However, evidence is emerging that drones have evolved mechanisms to protect sperm from the negative effects of infectious diseases, such as Nosema spp. Spores, or their detection by PCR, have been observed for both $N$. apis and $N$. ceranae in the ejaculates of drones (Peng et al. 2015; Roberts et al. 2015). Moreover, older drones infected with $N$. apis have decreased sperm viability (Peng et al.
2015). Inspection of seminal fluid has revealed the presence of protein and nonprotein factors that have high potency against $N$. apis spore viability. These factors act by inducing extracellular spore germination (Peng et al. 2016) and are associated with humoral immune response signaling and antimicrobial production (Grassl et al. 2017). Additional studies should confirm if the antimicrobial effects of seminal fluid are also effective against $N$. ceranae.

\section{EFFECTS ON WORKERS AND DISRUPTION OF THE DIVISION OF LABOR}

The regulatory interaction between $\mathrm{Vg}$ and juvenile hormone $(\mathrm{JH})$ provides one explanation for how honey bees express the sequence of behaviors homologous to the reproductive care exhibited by their solitary ancestors (Amdam et al. 2006). Experiments using RNAi or topical application of JH demonstrate how factors can interfere with the normal progression of worker ontogeny. For example, when $\mathrm{Vg}$ expression is suppressed via RNAi, JH titer spikes in nurse-aged bees, triggering premature foraging and a shortened lifespan (Guidugli et al. 2005; Amdam et al. 2007; Nelson et al. 2007; Marco Antonio et al. 2008). Application of JH produces similar effects when applied topically to nurse-aged bees (Robinson 1987; Robinson et al. 1989).

Physiological processes regulating host development are sensitive to parasites and pathogens (Hurd et al. 2001). For example, workers infected with Nosema spp. have elevated levels of JH (Fisher and Sanborn 1962; Liu 1989; Ares et al. 2012). In addition, Vg expression has been found to be depressed in infected nurse-aged workers (Antúnez et al. 2009; Goblirsch et al. 2013; Zheng et al. 2014; Garrido et al. 2016). Goblirsch et al. (2013) observed elevated Vg expression 16 days after infection with $N$. ceranae. Similar results were observed in infected queens (Alaux et al. 2011) and workers from colonies with low levels of infection (Antúnez et al. 2013). The pleiotropic role of $\mathrm{Vg}$ in the development of the queen and workers may provide insight in how its expression is affected by infection. 
Alteration of $\mathrm{Vg}$ and $\mathrm{JH}$ levels due to infection would likely manifest as expression of ageinappropriate behaviors and other physiological changes. Hypopharyngeal glands of nurse-aged bees infected with $N$. apis are reduced in size and function (Wang and Moeller 1969; Liu 1990). Workers infected with Nosema spp. have shortened lifespans and spend more time outside the nest engaged in risky behaviors such as guarding, orientation flights, and foraging (Hassanein 1953; Wang and Moeller 1970; Higes et al. 2008; Woyciechowski and Moroń 2009; Alaux et al. 2010; Vidau et al. 2011; Aufauvre et al. 2012, 2014; Lecocq et al. 2016; Natsopoulou et al. 2016). The site of Nosema spp. infection, the midgut, may be the direct source of downstream effects on $\mathrm{Vg}$ and/or JH. Since nurses typically consume large amounts of pollen that becomes digested and used for brood food synthesis, it is possible that suppression of $\mathrm{Vg}$ in infected bees is the result of changes to nutritional and metabolic pathways (Holt et al. 2013; Vidau et al. 2014). A recent meta-analysis comparing transcriptome datasets from honey bees infected with multiple pathogens suggests that downregulation of $\mathrm{Vg}$ and others genes coding for carbohydrate metabolism and detoxification is a general response to infection and not specific to Nosema spp. (Doublet et al. 2017).

Evidence from studies on $N$. apis and $N$. ceranae show that infection can disrupt worker age polyethism, mainly by advancing the transition from nursing to foraging (Wang and Moeller 1970; Goblirsch et al. 2013). Premature foraging may be a consequence of energetic demands that $N$. ceranae imposes on workers at a young age (Mayack and Naug 2009). Energetic stress imposed by infection can affect homing ability (Wolf et al. 2014). For example, the success rate of bees returning to their colony is significantly reduced for infected workers (Kralj and Fuchs 2010; Wolf et al. 2014). Additionally, there is a negative correlation between spore load and orientation flight duration and distance (Wolf et al. 2016). Despite having intact spatial processing capability (Wolf et al. 2016), the impact that reduced duration and distance covered during orientation has on an infected forager's output requires further study.
Workers infected with $N$. apis or $N$. ceranae have lower levels of trehalose, regardless of infection intensity (Mayack and Naug 2010; Kurze et al. 2016b). Low trehalose has been shown to reduce flying capability in bees infected with N. ceranae (Mayack and Naug 2010). Interestingly, flying capability can be restored if infected bees are given access to sucrose (Mayack and Naug 2010). The hypothesis that infected bees are "hungry" is supported by the finding that sucrose responsiveness is elevated in workers infected with $N$. ceranae and that these bees are less likely to share food with nestmates (Naug and Gibbs 2009). Ad libitum access to food may offset drains on carbohydrate and protein metabolism due to infection (Basualdo et al. 2014). In addition to energetic stress caused by parasitism, further research is needed to elucidate other mechanisms that may contribute to acceleration of behavioral maturation (Mayack et al. 2015).

The impact of Nosema spp. on development and physiology can be influenced by the age at which a bee becomes infected. One study looked at survival and parameters of immunity (e.g., prophenoloxidase and phenoloxidase) 12 days after workers of different ages were fed $N$. ceranae spores (Roberts and Hughes 2014). Although all age groups had the same duration of exposure, workers infected at an older age had higher spore loads yet were more likely to survive infection despite having a lower ability to mount an immune response (Roberts and Hughes 2014). This finding can be applied to explore infection dynamics at the colony level where older workers are more likely to be infected than younger workers (Jack et al. 2016).

Downstream effects from disruption of nutritional and metabolic pathways may also be evident by changes in pheromone production. Modulation of pheromone production has been shown in infected workers. Ethyl oleate (EO) is synthesized by older workers and has an inhibitory effect on behavioral development of younger workers. Older workers likely expose younger bees to EO during trophallaxis (Leoncini et al. 2004). Dussaubat et al. (2010) showed a positive correlation between spore load and EO production in infected bees. Because infection has been shown to cause workers to transition prematurely from 
nursing to foraging, elevated EO production may be an additional outcome of changes in underlying endocrine signaling that regulates pheromone synthesis.

$N$. ceranae affects individual bee lifespan directly through alteration of physiological and behavioral processes, but how can the pathological effects at the individual level lead to death of the colony? A honey bee colony has a complex structure where individuals perform age-specific tasks that maintain colony homeostasis. However, there is plasticity in the behavioral program of workers that allows them to respond to individual and colony stress. Workers can advance, delay, or revert to behaviors not typical for their age in response to colony need. For example, nurseaged bees can advance development to become foragers in response to a depopulation event of older workers, or they can delay onset to foraging if the current field force is confined to the hive during bouts of poor weather (Huang and Robinson 1996; Schulz et al. 1998; Amdam and Omholt 2003). Infection with $N$. ceranae can be one factor that alters the social demographics of the colony. The change in the age distribution of the worker population may be a direct response to infection. Infected bees die from tissue failure (Higes et al. 2007), are unable to return to the hive due to energetic stress (Kralj and Fuchs 2010; Wolf et al. 2014), or exit the hive to limit transmission to uninfected workers (Rueppell et al. 2010). The loss of infected workers, if sustained over time, may trigger accelerated aging and precocious foraging in uninfected nurse-aged workers. Precocious foragers are less effective at foraging than normal-aged foragers, resulting in food insecurity for the colony. The culmination of these effects could ultimately lead to sudden colony death (Perry et al. 2015).

\section{INTERACTIONS AND BEE HEALTH}

Many factors thought to contribute negatively to bee health likely do not act alone but are additive or synergistic with other stressors. Pesticides are one factor in which extensive research has been initiated to better understand their effects. Foraging bees are exposed to pesticides from the external environment during collection of nectar and pollen. Additionally, the hive environment can become contaminated through acaricides used to control $V$. destructor. Residues of over 100 different pesticides and their metabolites have been detected on bees or in pollen, honey, wax, and equipment (Bogdanov 2006; Chauzat and Faucon 2007; Frazier et al. 2008; Chauzat et al. 2009; Mullin et al. 2010; Lambert et al. 2013; Pettis et al. 2013). The amount of any individual pesticide frequently detected in the hive may not be sufficient to cause acute toxicity, but combinations of pesticides and/or their metabolites may have cumulative effects that create synergisms with other stressors such as pathogens, mites, or poor nutrition (Sanchez-Bayo and Goka 2014). For example, bees exposed to high levels of pesticides have been shown to be more susceptible to $N$. ceranae infection, and this increased risk is hypothesized to result from the inability of exposed bees to mount an effective immune response (Pettis et al. 2013).

Neonicotinoids and phenylpyrazoles are recent classes of insecticides with low toxicity to mammals. For this reason, they are used intensively to control arthropod pests. Sublethal doses of neonicotinoids combined with entomopathogenic fungi have become part of an integrated approach that utilizes two modes of action to enhance control (Purwar and Sachan 2006). The presence of these neonicotinoids in the environment could affect nontarget species such as bees harboring natural infections of Nosema spp. The interaction of chronic exposure to the neonicotinoids, imidacloprid and thiacloprid, with $N$. ceranae has been shown to increase mortality (Alaux et al. 2010; Retschnig et al. 2014b; although see Garrido et al. 2016). These findings are similar to studies examining the interaction of the phenylpyrazole, fipronil, with $N$. ceranae (Vidau et al. 2011; Aufauvre et al. 2012; but see Aufauvre et al. 2014). Neonicotinoids target the nervous system; however, these pesticides have been shown to induce apoptosis in midgut cells of larvae (Gregorc and Bowen 2000). To understand mechanisms of premature cell death, in vitro systems comprised of honey bee cells could be useful to observe cell death from exposure to combinations of pesticides and Nosema spp.

In addition to effects on survivorship, the interaction of pesticides and Nosema spp. infection 
may change the dynamics of the host-parasite relationship, such as allowing exploitation of host resources for spore production. Infected bees were found to have elevated spore loads after exposure to either neonicotinoids or phenylpyrazoles (Vidau et al. 2011; Pettis et al. 2012). One explanation for higher spore loads may be that Nosema spp. is opportunistic and takes advantage of the antibiotic potential of pesticides to reduce populations of beneficial symbionts in the gut that serve as a defense against invasion from foreign pathogens (Yoder et al. 2013).

Nosema spp. infection and pesticide exposure are ubiquitous events for a honey bee colony; therefore, it is difficult to tease apart which event, infection, or exposure occurs first and alters processes allowing the subsequent event to exacerbate the pathology. $N$. ceranae has been shown to upregulate cytochrome $\mathrm{P} 450$ monooxygenase and glutathione-S-transferase, and downregulate catalase and glutathione peroxidase in the midgut (Aufauvre et al. 2014). These genes metabolize foreign substrates for detoxification or provide protection against oxidative damage by catalyzing hydrogen peroxide to water and oxygen. Honey bees have half the P450 genes as some other insects (Claudianos et al. 2006). These findings provide clues as to the outcome when pesticides challenge the detoxification system of bees already overwhelmed from infection (Johnson et al. 2009). It could be that detoxification processes in the midgut become overwhelmed from exposure to pesticides, increasing susceptibility to infection.

\section{INTERACTION WITH VIRUSES}

Honey bees are host to $\geq 18$ viruses, most of which are nonenveloped, single-stranded, positive sense RNA viruses, or picornaviruses. Picornaviruses are highly prevalent and detrimental to bee health and productivity. Those viruses most frequently detected in beekeeping operations include black queen cell virus (BQCV), deformed wing virus (DWV), Kashmir bee virus (KBV), and sacbrood virus (SBV) (Chen and Siede 2007; Welch et al. 2009). Bailey et al. (1983) observed co-infections of BQCV and $N$. apis during a 3year observation period and showed that $\mathrm{BQCV}$ and $N$. apis cycled in unison, with levels of both pathogens peaking in May or June. Seasonal cycling of common viruses and Nosema spp. was demonstrated more recently with microarrays and deep sequencing of the honey bee microbiome using samples taken from a large-scale migratory operation (Runckel et al. 2011). These findings suggest that levels of acute bee paralysis virus, $\mathrm{BQCV}$, and SBV and $N$. ceranae peak in the summer and may act synergistically and contribute to colony failure.

The interaction of Nosema spp. and viruses has been reported for bees co-infected with $N$. ceranae and chronic bee paralysis virus (CBPV) or DWV. One study showed that co-infection of bees with $N$. ceranae and CBPV resulted in increased replication of CBPV but not mortality (Toplak et al. 2013). Costa et al. (2011) found a significant negative correlation between $N$. ceranae spore load and DWV titer in midgut tissues of workers. Furthermore, a survey of 322 colonies in Hawaii showed that while $\geq 89 \%$ were infected with $N$. ceranae, there was no correlation between spore load and DWV titer (Martin et al. 2013). One possible explanation why there is no positive correlation between spore load and DWV titer may depend on specific demographics of sampled bees. Bees symptomatic for DWV have viral replication in tissues throughout the body, which include hemolymph, gut, legs, head, thorax, abdomen, and most notably, the wings (Boncristiani et al. 2009). Food-borne transmission is one mechanism by which DWV can establish infection (Chen et al. 2006a, b). However, asymptomatic bees do not show signs of replication in the gut or abdomen, prompting speculation that a compromise in the integrity of the gut is needed for DWV to enter circulation via hemolymph (Boncristiani et al. 2009). Deformed wing virus can infect immature stages, whereas current evidence shows that the adult is the only life stage that can be infected naturally with Nosema spp. Newly emerged bees symptomatic for DWV die shortly after emergence (Chen et al. 2005; Dainat et al. 2012). Even if these bees were inoculated with spores upon emergence, the time until death may not be sufficient for Nosema spp. to complete its development and produce a large number of spores. On the other hand, asymptomatic bees appear relatively healthy 
and have a lifespan that supports spore production. $N$. apis and $N$. ceranae need $\geq 10$ days postinoculation to achieve fully developed infections (i.e. $\sim 20 \times 10^{6}$ spores/species) (Forsgren and Fries 2010). If a sample consists mainly of asymptomatic bees, it is possible that these bees have high spore loads but low DWV titer.

\section{INTERSPECIES TRANSMISSION}

As mentioned above, flowers may become contaminated with bee pathogens through visitation by host and nonhost vectors (Graystock et al. 2015). Through the sharing of floral resources, it is also possible that a pathogen can gain access to novel hosts. Infection with $N$. ceranae in other species has been examined. One study used cage experiments to infect different honey bee species, including the dwarf honey bee, Apis florea, and the giant honey bee, Apis dorsata, with isolates of N. ceranae from Canada and Thailand. Both species were susceptible to infection with the Thai isolate but the Canadian isolate was only infective against A. dorsata (Chaimanee et al. 2013). This finding adds support to an Asian origin for $N$. ceranae but may also demonstrate strain virulence in that the isolate from Canada was capable of producing an infection in A. mellifera as well.

Infection with $N$. ceranae has also been found in several species of Bombus from China (Li et al. 2012), Argentina (Plischuk et al. 2009), and the UK (Graystock et al. 2013; Fürst et al. 2014), albeit at low to moderate prevalence. In contrast, Arbulo et al. (2015) sampled Bombus atratus and Bombus bellicosus in Uruguay and found that the prevalence of $N$. ceranae infection approached $>50 \%$ in most areas sampled. $N$. ceranae may be associated with decline in abundance and richness of Bombus; however, much remains unknown (e.g., infectivity and pathogenicity) about the impact this pathogen is having on populations of these bees.

The use of bees other than honey bees for commercial pollination has led to the development of artificial rearing techniques for some species. Several species of solitary bee from the family Megachilidae, as well as some bumblebees, can be reared in the laboratory (Bosch and Kemp 2002; Evans et al. 2007), making it possible to study the effects of transmission to novel hosts from infection on metrics of individual bee and social living (e.g., foraging efficiency, survivorship, and reproductive success) in a controlled environment. For example, one study inoculated workers of Bombus terrestris with $6.5 \times 10^{3}$ N. ceranae spores and observed nearly $100 \%$ infection, spore amplification, and reduction in longevity (Graystock et al. 2013). However, this represents a subset of the thousands of other bees where the effects from Nosema spp. can only be assessed using anecdotal evidence, such as prevalence of infection. It is a challenge for future research to develop methods leading to an increase in the number of species that can either be reared in the laboratory or assessed by minimally invasive techniques (Paxton et al. 1997).

\section{TOLERANCE AS OPPOSED TO TREATMENT}

Past management for Nosema spp. has involved the use of the antifungal agent, fumagillin, applied prophylactically in the fall and/or spring (Webster 1994). This regime was intended to coincide with seasonal peaks of $N$. apis. However, evidence suggests that fumagillin may not be effective against $N$. ceranae (Williams et al. 2011; Huang et al. 2013). Huang et al. (2013) demonstrated that $N$. ceranae was able to withstand higher concentrations of fumagillin relative to $N$. apis, as measured by rate of spore production. Moreover, infected workers treated with relatively low concentrations of fumagillin had higher spores loads of $N$. ceranae than infected workers not treated with fumagillin (Huang et al. 2013).

In addition to having negative effects on host physiology, fumagillin increases management costs, and residues may persist in the hive, posing risks to human health through honey consumption (Lopez et al. 2008; van den Heever et al. 2015). Therefore, there is a need for alternatives to hard chemicals for Nosema spp. management. For example, ensuring that a colony has access to stored pollen helps sustain high hemolymph protein levels and promotes tolerance for $N$. ceranae infection (Basualdo et al. 2014). Another example of how this may be achieved is through selection of tolerant stocks (Holt and Grozinger 2016), as 
has been reported for colonies in Denmark (Huang et al. 2012). Recent research has identified physiological and molecular factors associated with tolerance to $N$. ceranae. Traits linked to tolerance are a lack of energetic stress (Kurze et al. 2016b) and increased survival despite high spore loads (Huang et al. 2014; Roberts and Hughes 2014). Huang et al. (2012) compared the immune response of tolerant drones to those from unselected colonies and found that tolerant drones had more robust activation of Toll signaling, an immune pathway responsive to Gram-positive bacterial and fungal infection. Tolerant bees also have increased levels of thioredoxin peroxidase, which may protect gut cells from the accumulation of reactive oxygen species produced as an immune response or pathogen-induced elevation of host metabolism (Kurze et al. 2016a). Colony level selection by beekeepers in Denmark for tolerance to Nosema spp. has likely led to reduction in genetic variability of specific regions of the honey bee genome (Huang et al. 2014). Analysis of differences between the genome of individuals under selection with those from unselected colonies could be useful for identifying molecular targets for RNAi-based treatments that confer host resistance.

\section{CONCLUSIONS}

Beekeepers and researchers have long dealt with Nosema spp. disease in colonies. Past observations on how infestations with the old Nosema sp., N. apis, contribute to queen failure, atypical worker ontogeny, and colony decline serve as a reference for understanding the current challenges imposed by the new Nosema. Comparative studies using caged bees infected with $N$. ceranae, $N$. apis, or both species have shed light on differences in parasite development and load. In addition to identifying differences in parasite virulence, caged bee studies, coupled with next generation sequencing, provide a platform to elucidate mechanisms of host tolerance at the molecular level. Although the prevalence of $N$. ceranae and $N$. apis fluctuates independently, high levels of $N$. ceranae during summer months provide opportunities to examine how this parasite may form synergisms with other common stressors of the hive environment such as pesticides and viruses.

\section{ACKNOWLEDGEMENTS}

I thank Katie Lee, Bridget Mendel Lee, and Marla Spivak, and two anonymous reviewers for providing critical feedback on this manuscript.

\section{AUTHOR'S CONTRIBUTION}

MG conceived and wrote the paper.

Nosema ceranae, champignon pathogène de l'abeille
(Apis mellifera)

Microsporidia / nosemose / comportement social / champignon parasite

Die Nosema ceranae Krankheit der Honigbiene (Apis mellifera )

pilzlicher Krankheitserreger / Microsporidia / Nosemose / Sozialverhalten

\section{REFERENCES}

Alaux, C., Brunet, J.L., Dussaubat, C., Mondet, F., Tchamitchan, S., Cousin, M., Brillard, J., Baldy, A., Belzunces, L.P., Le Conte, Y. (2010) Interactions between Nosema microspores and a neonicotinoid weaken honeybees (Apis mellifera). Environ. Microbiol. $12: 774-782$

Alaux, C., Folschweiller, M., McDonnell, C., Beslay, D., Cousin, M., Dussaubat, C., Brunet, J.L., Le Conte, Y. (2011) Pathological effects of the microsporidium Nosema ceranae on honey bee queen physiology (Apis mellifera). J. Invertebr. Pathol. $106: 380-385$

Amdam, G.V., Omholt, S.W. (2003) The hive bee to forager transition in honeybee colonies: the double repressor hypothesis. J. Theor. Biol. $223: 451-64$

Amdam, G.V., Csondes, A., Fondrk, M.K., Page, R.E. Jr. (2006) Complex social behavior derived from maternal reproductive traits. Nature 439 : 76-78

Amdam, G.V., Nilsen, K.A., Norberg, K., Fondrk, M.K., Hartfelder, K. (2007) Variation in endocrine signaling underlies variation in social life history. Am. Nat. $170: 37-46$

Antúnez, K., Martín-Hernández, R., Prieto, L., Meana, A., Zunino, P., Higes, M. (2009) Immune suppression in the honey bee (Apis mellifera) following infection by Nosema ceranae (Microsporidia). Environ. Microbiol. $11: 2284-2290$ 
Antúnez, K., Mendoza, Y., Santos, E., Invernizzi, C. (2013) Differential expression of vitellogenin in honey bees (Apis mellifera) with different degrees of Nosema ceranae infection. J. Apic. Res. $52: 227-234$

Arbulo, N., Antúnez, K., Salvarrey, S., Santos, E., Branchiccela, B., Martín-Hernández, R., Higes, M., Invernizzi, C. (2015) High prevalence and infection levels of Nosema ceranae in bumblebees Bombus atratus and Bombus bellicosus from Uruguay. J. Invertebr. Pathol. $130: 165-168$

Ares, A.M., Nozal, M.J., Bernal, J.L., Martín-Hernández, R., Higes, M., Bernal, J. (2012) Liquid chromatography coupled to ion trap-tandem mass spectrometry to evaluate juvenile hormone III levels in bee hemolymph from Nosema spp. infected colonies. J. Chromatogr. B Analyt. Technol. Biomed Life Sci. 899 :146-153

Aronstein, K.A., Webster, T.C., Saldivar, E. (2013) A serological method for detection of Nosema ceranae. J. Appl. Microbiol. 114:621-625

Aufauvre, J., Biron, D.G., Vidau, C., Fontbonne, R., Roudel, M., Diogon, M., Viguès, B., Belzunces, L.P., Delbac, F., Blot, N. (2012) Parasite-insecticide interactions: a case study of Nosema ceranae and fipronil synergy on honeybee. Sci. Rep. $2: 326$

Aufauvre, J., Misme-Aucouturier, B., Viguès, B., Texier, C., Delbac, F., Blot, N. (2014) Transcriptome analyses of the honeybee response to Nosema ceranae and insecticides. PLoS One. 9 :e91686

Baer, B., Armitage, S.A., Boomsma, J.J. (2006) Sperm storage induces an immunity cost in ants. Nature $441: 872-5$

Bailey, L., Ball, B.V., Perry, J.N. (1983) Association of viruses with two protozoal pathogens of the honey bee. Ann. Appl. Biol. 103 :13-20

Basualdo, M., Barragán, S., Antúnez, K. (2014) Bee bread increases honeybee haemolymph protein and promote better survival despite of causing higher Nosema ceranae abundance in honeybees. Environ. Microbiol. Rep. 6:396-400

Becnel, J.J., Andreadis, T.G. (1999) "Microsporidia in Insects". In: The Microsporidia and Microsporidiosis. Ed. M. Wittner. ASM Press, Washington DC, pp 447501

Bogdanov, S. (2006) Contamination of bee products. Apidologie 37:1-18

Boncristiani, H.F. Jr., Di Prisco, G., Pettis, J.S., Hamilton, M., Chen, Y.P. (2009) Molecular approaches to the analysis of deformed wing virus replication and pathogenesis in the honey bee, Apis mellifera. Virol. J. $6: 221$

Bosch, J., Kemp, W.P. (2002) Developing and establishing bee species as crop pollinators: the example of Osmia spp. and fruit trees. Bull. Entomol. Res. 92:3-16

Botías, C., Anderson, D.L., Meana, A., Garrido-Bailón, E., Martín-Hernández, R., Higes, M. (2012) Further evidence of an oriental origin for Nosema ceranae (Microsporidia: Nosematidae). J. Invertebr. Pathol. $110: 108-113$

Buys, B. (1972) Nosema in brood. S. Afr. Bee J. 44 :2-4
Cali, A., Neafie, R.C., Takorian, P.M. (2011) "Microsporidiosis". In: Topics on the Pathology of Protozoan and Invasive Arthropod Diseases. Eds. W.M. Meyers, A. Firpo, D.J. Wear. Armed Forces Institute of Pathology, Washington, DC, pp 1-25

Cantwell, G.E. (1970) Standard methods for counting Nosema spores. Am. Bee J. $110: 222-223$

Carletto, J., Blanchard, P., Gauthier, A., Schurr, F., Chauzat, M.P., Ribière, M. (2013) Improving molecular discrimination of Nosema apis and Nosema ceranae. J. Invertebr.Pathol. $113: 52-55$

Chaimanee, V., Pettis, J.S., Chen, Y., Evans, J.D., Khongphinitbunjong, K., Chantawannakul, P. (2013) Susceptibility of four different honey bee species to Nosema ceranae. Vet. Parasitol. $193: 260-265$

Chauzat, M.P., Faucon, J.P. (2007) Pesticide residues in beeswax samples collected from honey bee colonies (Apis mellifera L.) in France. Pest Manag. Sci. $63: 1100-1106$

Chauzat, M.P., Carpentier, P., Martel, A.C., Bougeard, S., Cougoule, N., Porta, P., Lachaize, J., Madec, F., Aubert, M., Faucon, J.P. (2009) Influence of pesticide residues on honey bee (Hymenoptera: Apidae) colony health in France. Environ. Entomol. 38:514-523

Chen, Y.P., Siede, R. (2007) Honey bee viruses. Adv. Virus Res. 70:33-80

Chen, Y.P., Higgins, J.A., Feldlaufer, M.F. (2005) Quantitative real-time reverse transcription PCR analysis of deformed wing virus infection in the honeybee (Apis mellifera L.). Appl. Environ. Microbiol. 71:436-441

Chen, Y., Evans, J., Feldlaufer, M. (2006a) Horizontal and vertical transmission of viruses in the honey bee, Apis mellifera. J. Invertebr. Pathol. $92: 152-159$

Chen, Y.P., Pettis, J.S., Collins, A., Feldlaufer, M.F. (2006b) Prevalence and transmission of honeybee viruses. Appl. Environ. Microbiol. 72 :606-611

Chen, Y., Evans, J.D., Smith, I.B., Pettis, J.S. (2008) Nosema ceranae is a long-present and wide spread microsporidian infection of the European honey bee (Apis mellifera) in the United States. J. Invertebr. Pathol. 97:186-188

Chen, Y.P., Evans, J.D., Murphy, C., Gutell, R., Zuker, M., Gundensen-Rindal, D., Pettis, J.S. (2009) Morphological, molecular and phylogenetic characterization of Nosema ceranae, a microsporidian parasite isolated from the European honey bee Apis mellifera. J. Eukaryot. Microbiol. 56:142-147

Chen, Y.P., Pettis, J.S., Zhao, Y., Liu, X., Tallon, L.J., et al. (2013) Genome sequencing and comparative genomics of honey bee microsporidia, Nosema apis reveal novel insights into host-parasite interactions. BMC Genomics. $14: 451$

Clark, T.B. (1980) A second microsporidian in the honeybee. J. Invertebr. Pathol. $35: 290-294$

Claudianos, C., Ranson, H., Johnson, R.M., Biswas, S., Schuler, M.A., Berenbaum, M.R., Feyereisen, R., Oakeshott, J.G. (2006) A deficit of detoxification enzymes: pesticide sensitivity and environmental response in the honeybee. Insect Mol. Biol. 15 :615-636 
Cohen, A.C. (2003) "Insect Diets: Science and Technology". CRC Press, Boca Raton, 324pp

Copley, T.R., Jabaji, S.H. (2012) Honeybee glands as possible infection reservoirs of Nosema ceranae and Nosema apis in naturally infected forager bees. J. Appl. Microbiol. $112: 15-24$

Cornman, R.S., Chen, Y.P., Schatz, M.C., Street, C., Zhao, Y., Desany, B., Egholm,M., Hutchison S, Pettis JS, Lipkin WI, Evans JD. (2009) Genomic analyses of the microsporidian Nosema ceranae, an emergent pathogen of honey bees. PLoS Pathog. 5 :e100046

Costa, C., Tanner, G., Lodesani, M., Maistrello, L., Neumann, P. (2011) Negative correlation between Nosema ceranae spore loads and deformed wing virus infection levels in adult honey bee workers. J. Invertebr. Pathol. 108:224-225

Cox-Foster, D.L., Conlan, S., Holmes, E.C., Palacios, G., Evans, J.D., et al. (2007) A metagenomic survey of microbes in honey bee colony collapse disorder. Science. 318 :283-287

Currie, R.W., Pernal, S.F., Guzman-Novoa, E. (2010) Honey bee colony losses in Canada. J. Apic. Res. 49:104-6

Dainat, B., Evans, J.D., Chen, Y.P., Gauthier, L., Neumann, P. (2012) Dead or alive: deformed wing virus and Varroa destructor reduce the life span of winter honeybees. Appl. Environ. Microbiol. 78:981-987

de Graaf, D.C., Raes, H., Sabbe, G., de Rycke, P.H., Jacobs, F.J. (1994) Early development of Nosema apis (Microspora: Nosematidae) in the midgut epithelium of the honeybee (Apis mellifera). J. Invertebr. Pathol. $63: 74-81$

den Boer, S. P, Baer, B., Boomsma, J.J. (2010) Seminal fluid mediates ejaculate competition in social insects. Science. $327: 1506-9$

Doublet, V., Poeschl, Y., Gogol-Döring, A., Alaux, C., Annoscia, D., et al. (2017) Unity in defence: honeybee workers exhibit conserved molecular responses to diverse pathogens. BMC Genomics. 18:207

Dussaubat, C., Maisonnasse, A., Alaux, C., Tchamitchan, S., Brunet, J.L., Plettner, E., Belzunces, L.P., Le Conte, Y. (2010) Nosema spp. infection alters pheromone production in honey bees (Apis mellifera). J. Chem. Ecol. $36: 522-525$

Dussaubat, C., Brunet, J.L., Higes, M., Colbourne, J.K., Lopez, J., et al. (2012) Gut pathology and responses to the microsporidium Nosema ceranae in the honey bee Apis mellifera. PLoS One. 7 :e37017

Dussaubat, C., Sagastume, S., Gómez-Moracho, T., Botías, C., García-Palencia, P., Martín Hernández, R., Le Conte, Y., Higes, M. (2013) Comparative study of Nosema ceranae (Microsporidia) isolates from two different geographic origins. Vet. Microbiol. $162: 670-678$

Eiri, D.M., Suwannapong, G., Endler, M., Nieh, J.C. (2015) Nosema ceranae can infect honey bee larvae and reduces subsequent adult longevity. PLoS One. $10: \mathrm{e} 0126330$

Emsen, B., Guzman-Novoa, E., Hamiduzzaman, M.M., Eccles, L., Lacey, B., Ruiz-Pérez, R.A., Nasr, M.
(2016) Higher prevalence and levels of Nosema ceranae than Nosema apis infections in Canadian honey bee colonies. Parasitol. Res. 115 :175-181

Evans, E., Burns, I., Spivak, M. (2007) “Befriending Bumble Bees: A Practical Guide to Raising Local Bumble Bees". University of Minnesota Extension Service, Minneapolis, 65pp

Farrar, C.L. (1947) Nosema losses in package bees as related to queen supersedure and honey yields. J. Econ. Entomol. $40: 333-338$

Fenoy, S., Rueda, C., Higes, M., Martín-Hernández, R., del Aguila, C. (2009) High-level resistance of Nosema ceranae, a parasite of the honeybee, to temperature and desiccation. Appl. Environ. Microbiol. 75 :68866889

Ferroglio, E., Zanet, S., Peraldo, N., Tachis, E., Trisciuoglio, A., Laurino, D., Porporato, M. (2013) Nosema ceranae has been infecting honey bees Apis mellifera in Italy since at least 1993. J. Apic. Res. $52: 60-61$

Fisher, F.M. Jr., Sanborn, R.C. (1962) Production of insect juvenile hormone by the microsporidian parasite Nosema. Natures 194:1193

Fluri, P., Sabatini, A.G., Vecchi, M.A., Wille, H. (1981) Blood juvenile hormone, protein and vitellogenin titres in laying and non-laying queen honeybees. J. Apic. Res. $20: 221-225$

Forsgren, E., Fries, I. (2010) Comparative virulence of Nosema ceranae and Nosema apis in individual European honey bees. Vet. Parasitol. $170: 212-17$

Frazier, M., Mullin, C., Frazier, J., Ashcraft, S. (2008) What have pesticides got to do with it? Am. Bee J. 148 :521523

Fries, I. (1988) Infectivity and multiplication of Nosema apis Z. in the ventriculus of the honey bee. Apidologie $19: 319-28$

Fries, I. (1989a) The intracellular development of Nosema apis Z. Apidologie. $20: 502-3$

Fries, I. (1989b) Observations on the development and transmission of Nosema apis Z. in the ventriculus of the honey bee. J. Apic. Res. $28: 107-17$

Fries, I. (1993) Nosema apis — a parasite in the honey bee colony. Bee World. $74: 5-19$

Fries, I., Feng, F., da Silva, A., Slemenda, S.B., Pieniazek, N.J. (1996) Nosema ceranae n. sp. (Microspora, Nosematidae), morphological and molecular characterization of a microsporidian parasite of the Asian honey bee Apis cerana (Hymenoptera, Apidae). Eur. J. Protistol. $32: 356-365$

Furgala, B. (1962) The effect on intensity of Nosema inoculum on queens supersedure in the honey bee, Apis mellifera Linnaeus. J. Insect. Pathol. 4 :429-432

Fürst, M.A., McMahon, D.P., Osborne, J.L., Paxton, R.J., Brown, M.J. (2014) Disease associations between honeybees and bumblebees as a threat to wild pollinators. Nature. 506:364-366

García-Palencia, P., Martín-Hernández, R., González-Porto, A.-V., Marin, P., Meana, A., Higes, M. (2010) Natural infection by Nosema ceranae causes similar 
lesions as in experimentally infected caged-worker honey bees (Apis mellifera). J. Apic. Res. 49:278-83

Garrido, P.M., Porrini, M.P., Antúnez, K., Branchiccela, B., Martínez-Noël, G.M., Zunino, P., Salerno, G., Eguaras, M.J., Ieno, E. (2016) Sublethal effects of acaricides and Nosema ceranae infection on immune related gene expression in honeybees. Vet. Res. 47:51

Gilliam, M., Shimanuki, H. (1967) In vitro phagocytosis of Nosema apis spores by honey bee hemocytes. J. Invertebr. Pathol. 9:387-389

Gisder, S., Hedtke, K., Möckel, N., Frielitz, M.C., Linde, A., Genersch, E. (2010) Five-year cohort study of Nosema spp. in Germany: does climate shape virulence and assertiveness of Nosema ceranae? Appl. Environ. Microbiol. 76:3032-3038

Goblirsch, M., Huang, Z.Y., Spivak, M. (2013) Physiological and behavioral changes in honey bees (Apis mellifera) induced by Nosema ceranae infection. PLoS One. 8 :e58165

Gómez-Moracho, T., Maside, X., Martín-Hernández, R., Higes, M., Bartolomé, C. (2014) High levels of genetic diversity in Nosema ceranae within Apis mellifera colonies. Parasitology $141: 475-481$

Grassl, J., Peng, Y., Baer-Imhoof, B., Welch, M., Millar, A.H., Baer, B. (2017) Infections with the sexually transmitted pathogen Nosema apis trigger an immune response in the seminal fluid of honey bees (Apis mellifera ). J. Proteome Res. 16:319-334

Gray, F.H., Cali, A., Briggs, J.D. (1969) Intracellular stages in the life cycle of the microsporidian Nosema apis . J. Invertebr. Pathol. 14:391-4

Graystock, P., Yates, K., Darvill, B., Goulson, D., Hughes, W.O. (2013) Emerging dangers: deadly effects of an emergent parasite in a new pollinator host. J. Invertebr. Pathol. 114 :114-119

Graystock, P., Goulson, D., Hughes, W.O. (2015). Parasites in bloom: flowers aid dispersal and transmission of pollinator parasites within and between bee species. Proc. Biol. Sci. 282

Gregorc, A., Bowen, I.D. (2000) Histochemical characterization of cell death in honeybee larvae midgut after treatment with Paenibacillus larvae, Amitraz and Oxytetracycline. Cell Biol. Int. $24: 319-324$

Gregorc, A., Silva-Zacarin, E.C., Carvalho, S.M., Kramberger, D., Teixeira, E.W., Malaspina, O. (2016) Effects of Nosema ceranae and thiamethoxam in Apis mellifera: a comparative study in Africanized and Carniolan honey bees. Chemosphere 147:328-336

Guerrero-Molina, C., Correa-Benítez, A., Hamiduzzaman, M.M., Guzman-Novoa, E. (2016) Nosema ceranae is an old resident of honey bee (Apis mellifera) colonies in Mexico, causing infection levels of one million spores per bee or higher during summer and fall. J. Invertebr. Pathol. $141: 38-40$

Guidugli, K.R., Nascimento, A.M., Amdam, G.V., Barchuk, A.R., Omholt, S., Simões, Z.L.P., Hartfelder, K. (2005) Vitellogenin regulates hormonal dynamics in the worker caste of a eusocial insect. FEBS Lett. 579 : $4961-4965$
Hacker, C., Howell, M., Bhella, D., Lucocq, J. (2014) Strategies for maximizing ATP supply in the microsporidian Encephalitozoon cuniculi : direct binding of mitochondria to the parasitophorous vacuole and clustering of the mitochondrial porin VDAC. Cell. Microbiol. 16:565-79

Hagedorn, H.H., Kunkel, J.G. (1979) Vitellogenin and vitellin in insects. Annu. Rev. Entomol. 24 :475-505

Hassanein, M.H. (1953) The influence of infection with Nosema apis on the activities and longevity of the worker honeybee. Ann. Appl. Biol. 40 :418-423

Higes, M., Martín, R., Meana, A. (2006) Nosema ceranae, a new microsporidian parasite in honeybees in Europe. J. Invertebr. Pathol. $92: 93-5$

Higes, M., García-Palencia, P., Martín-Hernández, R., Meana, A. (2007) Experimental infection of Apis mellifera honeybees with Nosema ceranae (Microsporidia). J. Invertebr. Pathol. 94 :211-217

Higes, M., Martín-Hernández, R., Garrido-Bailón, E., García-Palencia, P., Meana, A. (2008) Detection of infective Nosema ceranae (Microsporidia) spores in corbicular pollen of forager honeybees. J. Invertebr. Pathol. 97 :76-78

Higes, M., Martín-Hernández, R., García-Palencia, P., Marín, P., Meana, A. (2009) Horizontal transmission of Nosema ceranae (Microsporidia) from worker honeybees to queens (Apis mellifera). Environ. Microbiol. Rep. $1: 495-498$

Higes, M., Juarranz, Á., Dias-Almeida, J., Lucena, S., Botías, C., Meana, A., García Palencia, P., MartínHernández, R. (2013a) Apoptosis in the pathogenesis of Nosema ceranae (Microsporidia: Nosematidae) in honey bees (Apis mellifera ). Environ. Microbiol. Rep. 5:530-536

Higes, M., Meana, A., Bartolomé, C., Botías, C., MartínHernández, R. (2013b) Nosema ceranae (Microsporidia), a controversial 21st century honey bee pathogen. Environ. Microbiol. Rep. 5 :17-29

Holt, H.L., Grozinger, C.M. (2016) Approaches and challenges to managing Nosema (Microspora: Nosematidae) parasites in honey bee (Hymenoptera: Apidae) colonies. J. Econ. Entomol. 109 :1487-1503

Holt, H.L., Aronstein, K.A., Grozinger, C.M. (2013) Chronic parasitization by Nosema microsporidia causes global expression changes in core nutritional, metabolic and behavioral pathways in honey bee workers (Apis mellifera). BMC Genomics. 14 :799

Huang, Z.-Y., Robinson, G.E. (1996) Regulation of honey bee division of labor by colony age demography. Behav. Ecol. Sociobiol. $39: 147-58$

Huang, W.F., Solter, L.F. (2013) Comparative development and tissue tropism of Nosema apis and Nosema ceranae. J. Invertebr. Pathol. 113 :35-41

Huang, W.-F., Jiang, J.-H., Chen, Y.-W., Wang, C.-H. (2007) A Nosema ceranae isolate from the honeybee Apis mellifera. Apidologie 38:30-7

Huang, Q., Kryger, P., Le Conte, Y., Moritz, R.F. (2012) Survival and immune response of drones of a Nosemosis tolerant honey bee strain towards 
N. ceranae infections. J. Invertebr. Pathol. $109: 297-$ 302

Huang, W.F., Solter, L.F., Yau, P.M., Imai, B.S. (2013) Nosema ceranae escapes fumagillin control in honey bees. PLoS. Pathog. 9 :e1003185

Huang, Q., Lattorff, H.M., Kryger, P., Le Conte, Y., Moritz, R.F. (2014) A selective sweep in a microsporidian parasite Nosema-tolerant honeybee population, Apis mellifera. Anim Genet. 45 :267-273

Huang, Q., Chen, Y.P., Wang, R.W., Cheng, S., Evans, J.D. (2016) Host-parasite interactions and purifying selection in a microsporidian parasite of honey bees. PLoS One. 11 :e0147549

Hurd, H., Warr, E., Polwart, A. (2001) A parasite that increases host lifespan. Proc. R. Soc. Lond. B. $268: 1749-1753$

Invernizzi, C., Abud, C., Tomasco, I.H., Harriet, J., Ramallo, G., Campá, J., Katz, H., Gardiol, G., Mendoza, Y. (2009) Presence of Nosema ceranae in honeybees (Apis mellifera) in Uruguay. J. Invertebr. Pathol. 101 :150-3

Jack, C.J., Lucas, H.M., Webster, T.C., Sagili, R.R. (2016) Colony level prevalence and intensity of Nosema ceranae in honey bees (Apis mellifera L.). PLoS One. $11: \mathrm{e} 0163522$

Jay, S.C. (1967) The problem of infertile and Nosemainfected queens. Manitoba Entomol. $1: 14-17$

Johnson, R.M., Evans, J.D., Robinson, G.E., Berenbaum, M.R. (2009) Changes in transcript abundance relating to colony collapse disorder in honey bees (Apis mellifera). Proc. Natl. Acad. Sci. U.S.A. 106:14790-14795

Klee, J., Besana, A.M., Genersch, E., Gisder, S., Nanetti, A., et al. (2007) Widespread dispersal of the microsporidian Nosema ceranae, an emergent pathogen of the western honey bee, Apis mellifera. J. Invertebr. Pathol. $96: 1-10$

Kralj, J., Fuchs, S. (2010) Nosema sp. influences flight behaviour of infected honeybee (Apis mellifera) foragers. Apidologie. $41: 21-28$

Kumar, V., Abbas, A.K., Aster, J.C. (2012) "Cell Injury, Cell Death, and Adaptations". In: Robbins Basic Pathology. 9th edn. Elsevier Saunders, Philadelphia, pp $1-29$

Kurze, C., Dosselli, R., Grasslb, J., Le Conte, Y., Kryger, P., Baer, B., Moritz, R.F.A. (2016a) Differential proteomics reveals novel insights into Nosema-honey bee interactions. Insect Biochem. Mol. Biol. 79:1-12

Kurze, C., Mayack, C., Hirche, F., Stangl, G.I., Le Conte, Y., Kryger, P., Moritz, R.F. (2016b) Nosema spp. infections cause no energetic stress in tolerant honeybees. Parasitol Res. $115: 2381-2388$

Lambert, O., Piroux, M., Puyo, S., Thorin, C., L'Hostis, M., Wiest, L., Buleté, A., Delbac, F., Pouliquen, H. (2013) Widespread occurrence of chemical residues in beehive matrices from apiaries located in different landscapes of Western France. PLoS One. 8 :e67007

Laurent, M., Hendrikx, P., Ribiere-Chabert, M., Chauzat, M.-P. (2016) A pan-European epidemiological study on honeybee colony losses 2012-2014. Sophia Antipolis: European Union Reference Laboratory for honey bee health (EURL)

Lecocq, A., Jensen, A.B., Kryger, P., Nieh, J.C. (2016) Parasite infection accelerates age polyethism in young honey bees. Sci Rep. $6: 22042$

Leoncini, I., Le Conte, Y., Costagliola, G., Plettner, E., Toth, A.L., Wang, M., Huang, Z., Bécard, J.M., Crauser, D., Slessor, K.N., Robinson, G.E. (2004) Regulation of behavioral maturation by a primer pheromone produced by adult worker honey bees. Proc. Natl. Acad. Sci. U.S.A. 101 :17559-17564

Li, J., Chen, W., Wu, J., Peng, W., An, J., Schmid-Hempel, P., Schmid-Hempel, R. (2012) Diversity of Nosema associated with bumblebees (Bombus spp.) from China. Int. J.Parasitol. 42 :49-61

Liu, T.P. (1984) Ultrastructure of the midgut of the worker honeybee Apis mellifera heavily infected with Nosema apis. J. Invertebr. Pathol. 44 :282-291

Liu, T.P. (1989) Juvenile hormone III induced ultrastructural changes in the hypopharyngeal glands of honeybee Apis mellifera L. (Hymenoptera: Apidae) without and with infection by Nosema apis Zander (Microsporidia: Nosematidae). Int. J. Insect Morphol. Embryol. $18: 73-83$

Liu, T.P. (1990) Ultrastructural analysis on the gland secretion in the extracellular ducts of the hypopharyngeal glands of the honeybee infected by Nosema apis. Tissue Cell. 22 :533-540

Liu, T.P. (1992) Oöcytes degeneration in the queen honey bee after infection by Nosema apis. Tissue Cell. 24:131-138

Lopez, M.I., Pettis, J.S., Smith, I.B., Chu, P.S. (2008) Multiclass determination and confirmation of antibiotic residues in honey using LC-MS/MS. J. Agric. Food Chem. $56: 1553-1559$

Malone, L.A., Gatehouse, H.S. (1998) Effects of Nosema apis infection on honey bee (Apis mellifera) digestive proteolytic enzyme activity. J. Invertebr. Pathol. $71: 169-174$

Malone, L.A., Gatehouse, H.S., Tregidga, E.L. (2001) Effects of time, temperature, and honey on Nosema apis (Microsporidia: Nosematidae), a parasite of the honeybee, Apis mellifera (Hymenoptera: Apidae). J. Invertebr. Pathol. $77: 258-268$

Marco Antonio, D.S., Guidugli-Lazzarini, K.R., do Nascimento, A.M., Simões, Z.L., Hartfelder, K. (2008) RNAi-mediated silencing of vitellogenin gene function turns honeybee (Apis mellifera) workers into extremely precocious foragers. Naturwissenschaften 95 : $953-961$

Martin, S.J., Hardy, J., Villalobos, E., Martín-Hernández, R., Nikaido, S., Higes, M. (2013) Do the honeybee pathogens Nosema ceranae and deformed wing virus act synergistically? Environ. Microbiol. Rep. 5 :506510

Martín-Hernández, R., Meana, A., García-Palencia, P., Marín, P., Botías, C., Garrido Bailón, E., Barrios, L., Higes, M. (2009) Effect of temperature on the biotic 
potential of honeybee microsporidia. Appl. Environ. Microbiol. 75 :2554-2557

Martín-Hernández, R., Botías, C., Bailón, E.G., MartínezSalvador, A., Prieto, L., Meana, A., Higes, M. (2012) Microsporidia infecting Apis mellifera: coexistence or competition. Is Nosema ceranae replacing Nosema apis? Environ. Microbiol. $14: 2127-38$

Mayack, C., Naug, D. (2009) Energetic stress in the honeybee Apis mellifera from Nosema ceranae infection. J. Invertebr. Pathol. $100: 185-188$

Mayack, C., Naug, D. (2010) Parasitic infection leads to decline in hemolymph sugar levels in honeybee foragers. J. Insect Physiol. 56:1572-1575

Mayack, C., Natsopoulou, M.E., McMahon, D.P. (2015) Nosema ceranae alters a highly conserved hormonal stress pathway in honeybees. Insect Mol. Biol. 24:662-670

McGowan, J., De la Mora, A., Goodwin, P.H., Habash, M., Hamiduzzaman, M.M., Kelly, P.G., Guzman-Novoa, E. (2016) Viability and infectivity of fresh and cryopreserved Nosema ceranae spores. J. Microbiol. Methods. $131: 16-22$

Meana, A., Martín-Hernández, R., Higes, M. (2010) The reliability of spore counts to diagnose Nosema ceranae infections in honey bees. J. Apic. Res. 49 :212-214

Milbrath, M.O., van Tran, T., Huang, W.F., Solter, L.F., Tarpy, D.R., Lawrence, F., Huang, Z.Y. (2015) Comparative virulence and competition between Nosema apis and Nosema ceranae in honey bees (Apis mellifera ). J. Invertebr. Pathol. $125: 9-15$

Moeller, F.E. (1972) Effect of emerging bees and of winter flights on nosema disease in honey bee colonies. J. Apic. Res. $11: 117-120$

Mulholland, G.E., Traver, B.E., Johnson, N.G., Fell, R.D. (2012) Individual variability of Nosema ceranae infections in Apis mellifera colonies. Insects 3:11431155

Mullin, C.A., Frazier, M., Frazier, J.L., Ashcraft, S., Simonds, R., van Engelsdorp, D., Pettis, J.S. (2010) High levels of miticides and agrochemicals in North American apiaries: implications for honey bee health. PLoS One. 5 :e9754

Nash, P.B., Purner, M.B., Leon, R.P., Clarke, P., Duke, R.C., Curiel, T.J. (1998) Toxoplasma gondii infected cells are resistant to multiple inducers of apoptosis. J. Immunol. $160: 1824-1830$

Natsopoulou, M.E., McMahon, D.P., Paxton, R.J. (2016) Parasites modulate within-colony activity and accelerate the temporal polyethism schedule of a social insect, the honey bee. Behav. Ecol. Sociobiol. 70 :1019-1031

Naug, D., Gibbs, A. (2009) Behavioral changes mediated by hunger in honeybees infected with Nosema ceranae. Apidologie. 40 :595-599

Nelson, C.M., Ihle, K.E., Fondrk, M.K., Page, R.E., Amdam, G.V. (2007) The gene vitellogenin has multiple coordinating effects on social organization. PLoS Biol. 5 :e62
Paxton, R.J., Fries, I., Pieniazekc, N.J., Tengöd, J. (1997) High incidence of infection of an undescribed microsporidium (Microspora) in the communal bee Andrena scotica (Hymenoptera, Andrenidae). Apidologie. $28: 129-141$

Paxton, R.J., Klee, J., Korpela, S., Fries, I. (2007) Nosema ceranae has infected Apis mellifera in Europe since at least 1998 and may be more virulent than Nosema apis. Apidologie 38:558-565

Peng, Y., Lee-Pullen, T.F., Heel, K., Millar, A.H., Baer, B. (2014) Quantifying spore viability of the honey bee pathogen Nosema apis using flow cytometry. Cytometry A. $85: 454-462$

Peng, Y., Baer-Imhoof, B., Millar, A.H., Baer, B. (2015) Consequences of Nosema apis infection for male honey bees and their fertility. Sci Rep. 5 :10565

Peng, Y., Grassl, J., Millar, A.H., Baer, B. (2016) Seminal fluid of honeybees contains multiple mechanisms to combat infections of the sexually transmitted pathogen Nosema apis. Proc. Biol. Sci. $\mathbf{2 8 3}$

Perry, C.J., Søvik, E., Myerscough, M.R., Barron, A.B. (2015) Rapid behavioral maturation accelerates failure of stressed honey bee colonies. Proc. Natl. Acad. Sci. U.S.A. $112: 3427-32$

Pettis, J.S., van Engelsdorp, D., Johnson, J., Dively, G. (2012) Pesticide exposure in honey bees results in increased levels of the gut pathogen Nosema. Natuurwet. 99 :153-158

Pettis, J.S., Lichtenberg, E.M., Andree, M., Stitzinger, J., Rose, R., van Engelsdorp, D. (2013) Crop pollination exposes honey bees to pesticides which alters their susceptibility to the gut pathogen Nosema ceranae. PLoS One. 8 :e70182

Piiroinen, S., Goulson, D. (2016) Chronic neonicotinoid pesticide exposure and parasite stress differentially affects learning in honeybees and bumblebees. Proc. Biol. Sci. 283

Plischuk, S., Martín-Hernández, R., Prieto, L., Lucía, M., Botías, C., Meana, A., Abrahamovich, A.H., Lange, C., Higes, M. (2009) South American native bumblebees (Hymenoptera: Apidae) infected by Nosema ceranae (Microsporidia), an emerging pathogen of honeybees (Apis mellifera). Environ. Microbiol. Rep. $1: 131-135$

Ptaszyńska, A.A., Borsuk, G., Woźniakowski, G., Gnat, S., Małek, W. (2014) Loop mediated isothermal amplification (LAMP) assays for rapid detection and differentiation of Nosema apis and N. ceranae in honeybees. FEMS Microbiol. Lett. 357 :40-48

Purwar, J.P., Sachan, G.C. (2006) Synergistic effect of entomogenous fungi on some insecticides against Bihar hairy caterpillar Spilarctia obliqua (Lepidoptera: Arctiidae). Microbiol. Res. $161: 38-42$

Raina, S.K., Das, S., Rai, M.M., Khurad, A.M. (1995) Transovarial transmission of Nosema Locustae (Microsporidia: Nosematidae) in the migratory locust Locusta migratoria migratorioides. Parasitol. Res. $81: 38-44$

Retschnig, G., Neumann, P., Williams, G.R. (2014a) Thiacloprid-Nosema ceranae interactions in honey 
bees: host survivorship but not parasite reproduction is dependent on pesticide dose. J. Invertebr. Pathol. 118: $18-19$

Retschnig, G., Williams, G.R., Mehmann, M.M., Yañez, O., de Miranda, J.R., Neumann, P. (2014b) Sex specific differences in pathogen susceptibility in honey bees (Apis mellifera). PLoS One. 9 :e85261

Retschnig, G., Williams, G.R., Schneeberger, A., Neumann, P. (2017) Cold ambient temperature promotes Nosema spp. intensity in honey bees (Apis mellifera). Insects 8:20

Roberts, K.E., Hughes, W.O. (2014) Immunosenescence and resistance to parasite infection in the honey bee, Apis mellifera. J. Invertebr. Pathol. 121:1-6

Roberts, K.E., Evison, S.E., Baer, B., Hughes, W.O. (2015) The cost of promiscuity: sexual transmission of Nosema microsporidian parasites in polyandrous honey bees. Sci. Rep. $5: 10982$

Robinson, G.E. (1987) Regulation of honey bee age polyethism by juvenile hormone. Behav Ecol Sociobiol. $20: 329-338$

Robinson, G.E., Page, R.E. Jr., Strambi, C., Strambi, A. (1989) Hormonal and genetic control of behavioral integration in honey bee colonies. Science. 246:109-112

Rueppell, O., Hayworth, M.K., Ross, N.P. (2010) Altruistic self-removal of health-compromised honey bee workers from their hive. J. Evol. Biol. 23 :1538-46

Runckel, C., Flenniken, M.L., Engel, J.C., Ruby, J.G., Ganem, D., Andino, R., DeRisi, J.L. (2011) Temporal analysis of the honey bee microbiome reveals four novel viruses and seasonal prevalence of known viruses, Nosema, and Crithidia. PLoS One. 6 :e20656

Sagastume, S., del Aguila, C., Martín-Hernández, R., Higes, M., Henriques-Gil, N. (2011) Polymorphism and recombination for rDNA in the putatively asexual microsporidian Nosema ceranae, a pathogen of honeybees. Environ. Microbiol. 13 :84-95

Sánchez Collado, J.G., Higes, M., Barrio, L., MartínHernández, R. (2014) Flow cytometry analysis of Nosema species to assess spore viability and longevity. Parasitol Res. 113 :1695-1701

Sanchez-Bayo, F., Goka, K. (2014) Pesticide residues and bees - a risk assessment. PLoS One. 9 :e94482

Scanlon, M., Leitch, G.J., Shaw, A.P., Moura, H., Visvesvara, G.S. (1999) Susceptibility to apoptosis is reduced in the Microsporidia-infected host cell. J. Eukaryot. Microbiol. 46:34S-35S

Scanlon, M., Leitch, G.J., Visvesvara, G.S., Shaw, A.P. (2004) Relationship between the host cell mitochondria and the parasitophorous vacuole in cells infected with Encephalitozoon microsporidia. J. Eukaryot. Microbiol. $51: 81-7$

Schulz, D.J., Huang, Z.-Y., Robinson, G.E. (1998) Effects of colony food shortage on behavioral development in honey bees. Behav. Ecol. Sociobiol. 42 :295-303

Smith, M.L. (2012) The honey bee parasite Nosema ceranae: transmissible via food exchange? PLoS One. $7:$ e43319
Snow, J.W. (2016) A fluorescent method for visualization of Nosema infection in whole-mount honey bee tissues. J. Invertebr. Pathol. $135: 10-14$

Teixeira, E.W., Santos, L.G., Sattler, A., Message, D., Alves, M.L., Martins, M.F., Grassi Sella, M.L., Francoy, T.M. (2013) Nosema ceranae has been present in Brazil for more than three decades infecting Africanized honey bees. J. Invertebr. Pathol. $114: 250-254$

Terry, R.S., Dunn, A.M., Smith, J.E. (1997) Cellular distribution of a feminizing microsporidian parasite: a strategy for transovarial transmission. Parasitology $115: 157-163$

Toplak, I., Jamnikar Ciglenečki, U., Aronstein, K., Gregorc, A. (2013) Chronic bee paralysis virus and Nosema ceranae experimental co-infection of winter honey bee workers (Apis mellifera L.). Viruses $5: 2282-2297$

Traver, B.E., Fell, R.D. (2011a) Prevalence and infection intensity of Nosema in honey bee (Apis mellifera L.) colonies in Virginia. J. Invertebr. Pathol. 107:43-49

Traver, B.E., Fell, R.D. (2011b) Nosema ceranae in drone honey bees (Apis mellifera). J. Invertebr. Pathol. $107: 234-236$

Traver, B.E., Fell, R.D. (2015) A scientific note: survey for Nosema spp. in preserved Apis spp. Apidologie 46:194-6

Tsaousis, A.D., Kunji, E.R., Goldberg, A.V., Lucocq, J.M., Hirt, R.P., Embley, T.M. (2008) A novel route for ATP acquisition by the remnant mitochondria of Encephalitozoon cuniculi. Nature 453 :553-6

van den Heever, J.P., Thompson, T.S., Curtis, J.M., Pernal, S.F. (2015) Stability of dicyclohexylamine and fumagillin in honey. Food Chem. $179: 152-158$

Vidau, C., Diogon, M., Aufauvre, J., Fontbonne, R., Viguès, B., Brunet, J.L., Texier, C., Biron, D.G., Blot, N., El Alaoui, H., Belzunces, L.P., Delbac, F. (2011) Exposure to sublethal doses of fipronil and thiacloprid highly increases mortality of honeybees previously infected by Nosema ceranae. PLoS One. 6 :e21550

Vidau, C., Panek, J., Texier, C., Biron, D.G., Belzunces, L.P., Le Gall, M., Broussard, C., Delbac, F., El Alaoui, H. (2014) Differential proteomic analysis of midguts from Nosema ceranae infected honeybees reveals manipulation of key host functions. J. Invertebr. Pathol. $121: 89-96$

Wang, D.I., Moeller, F.E. (1969) Histological comparisons of the development of the hypopharyngeal glands in healthy and Nosema-infected worker honey bees. J. Invertebr. Pathol. 14 :135-142

Wang, D.I., Moeller, F.E. (1970) The division of labor and queen attendance behavior of Nosema infected worker honeybees. J. Econ. Entomol. 63 :1540-1541

Webster, T.C. (1994) Fumagillin affects Nosema apis and honey bees (Hymonoptera - Apidae). J. Econ. Entomol. 87 :601-604

Weeks, A.R., Hoffmann, A.A. (2008) Frequencydependent selection maintains clonal diversity in an asexual organism. Proc. Natl. Acad. Sci. U.S.A. $105: 17872-17877$ 
Welch, A., Drummond, F., Tewari, S., Averill, A., Burand, J.P. (2009) Presence and prevalence of viruses in local and migratory honeybees (Apis mellifera) in Massachusetts. Appl. Environ. Microbiol. 75:7862-7865

Williams, G.R., Shafer, A.B.A., Rogers, R.E.L., Shutler, D., Stewart, D.T. (2008) First detection of Nosema ceranae, a microsporidian parasite of European honey bees (Apis mellifera), in Canada and central USA. J. Invertebr. Pathol. 97:189-192

Williams, G.R., Shutler, D., Little, C.M., BurgherMacLellan, K.L., Rogers, R.E.L. (2011) The microsporidian Nosema ceranae, the antibiotic Fumagillin-B (R), and western honey bee (Apis mellifera ) colony strength. Apidologie. 42:15-22

Williams, G.R., Shutler, D., Burgher-MacLellan, K.L., Rogers, R.E. (2014) Infra-population and community dynamics of the parasites Nosema apis and Nosema ceranae, and consequences for honey bee (Apis mellifera) hosts. PLoS One. 9 :e99465

Wolf, S., McMahon, D.P., Lim, K.S., Pull, C.D., Clark, S.J., Paxton, R.J., Osborne, J.L. (2014) So near and yet so far: harmonic radar reveals reduced homing ability of Nosema infected honeybees. PLoS One. 9 :e103989

Wolf, S., Nicholls, E., Reynolds, A.M., Wells, P., Lim, K.S., Paxton, R.J., Osborne, J.L. (2016) Optimal search patterns in honeybee orientation flights are robust against emerging infectious diseases. Sci. Rep. $6: 32612$

Woyciechowski, M., Moroń, D. (2009) Life expectancy and onset of foraging in the honeybee (Apis mellifera). Insectes Soc. 56:193-201

Xu, Y., Weiss, L.M. (2005) The microsporidian polar tube: a highly specialized invasion organelle. Int. J. Parasitol. 35:941-53

Yoder, J.A., Jajack, A.J., Rosselot, A.E., Smith, T.J., Yerke, M.C., Sammataro, D. (2013) Fungicide contamination reduces beneficial fungi in bee bread based on an area wide field study in honey bee, Apis mellifera, colonies. J. Toxicol. Environ. Health A. 76:587-600

Youssef, N.N., Hammond, D.M. (1971) The fine structure of the developmental stages of the microsporidian Nosema apis Zander. Tissue Cell. 3 :283-94

Zander, E. (1909) Tierische Parasiten als Krankenheitserreger bei der Biene. Münchener Bienenztg. 31 :196-204

Zheng, H.Q., Lin, Z.G., Huang, S.K., Sohr, A., Wu, L., Chen, Y.P. (2014) Spore loads may not be used alone as a direct indicator of the severity of Nosema ceranae infection in honey bees Apis mellifera (Hymenoptera: Apidae). J. Econ. Entomol. 107 :2037-2044 